\title{
Stock Market Integration: Are Risk Premiums of International Assets Equal?*
}

\author{
Kusdhianto Setiawan \\ Faculty of Economics and Business, Universitas Gadjah Mada, Indonesia
}

\begin{abstract}
This paper studies previous research on capital market integration and applies a simple international capital asset pricing model by considering the incompleteness in market integration and heteroscedasticity of the market returns. When we disregarded those two factors, we found that stock markets were integrated and the law of one price on risk premiums prevails. However, when the factors were considered, the markets were just partially integrated.

Abstrak: Paper ini meninjau kembali berbagai penelitian sebelumnya dibidang integrasi pasar modal dan menerapkan International Capital Asset Pricing Model sederhana dengan mempertimbangkan faktor ketidaksempurnaan integrasi pasar dan faktor heteroskedastisitas dari pengembalian pasar. Ketika kedua faktor tersebut diabaikan, studi ini menemukan bahwa hukum satu harga (atas risiko pasar suatu aset atau premi risiko) berlaku dan berbagai pasar modal yang dijadikan sampel terintegrasi. Namun, ketika kedua faktor tersebut dipertimbangkan, berbagai pasar modal tersebut hanya terintegrasi secara parsial.
\end{abstract}

Keywords: international CAPM; market integration; risk premium

JEL Codes: G11, G12, G15

* This article is a part of the author's dissertation at Hiroshima University of Economics.

* Corresponding author's e-mail: s.kusdhianto@ugm.ac.id 


\section{Introduction}

The introduction of the euro in European countries is often cited as an example of the countries' ultimate goal of being merged into a single market. Before the introduction of the single currency, the European Union (EU) countries harmonized their trade policies and made freer the trade of goods, services, and human capital (labor market integration) among the members. Meanwhile, the ASEAN countries seem to follow the steps taken by the EU in liberalizing their markets. However, the use of a single currency in the ASEAN group seems not to be expected in the near future. Many studies linked the steps necessary to integrate the markets to the theory of the optimum currency area (OCA). The theory of the OCA, first proposed by Mundell (1963) is what inspires such market integration efforts. There is a general consensus that economic liberalization in emerging economies should begin with trade liberalization and be followed by the deregulation of domestic financial markets before lifting restrictions on capital account transactions (Park and Wyplosz 2010: 41).

The East Asian countries, especially the ASEAN countries, have largely followed the sequencing strategy; they started lowering tariffs and non-tariff barriers long before taking steps to liberalize and open their financial markets. Thus, the markets might be regionally integrated, but in a worldwide context, they are not completely integrated.

If financial liberalization is to be effective, the financial market in a country must, at the very least, be partially integrated with the world's financial markets. In this case, both the domestic market and world market risks are prominent factors in pricing assets traded in the market. In the case of the emerging financial markets, especially those in Asia, where the intensity of the market liberalization processes is the highest, the market might only be regionally integrated because after liberalization, significant indirect barriers remain in place, so that the efforts fail to attract foreign (offshore) investments. However, as the process of integration is continuously taking place around the world, the state of integration might change in the future. Regarding the issues, the measure of market integration must be, in some circumstances, time-varying in-so-far as emerging markets may evolve from a segmented state to an integrated state through time and vice versa (Arouri et al. 2010).

In the case of fully integrated markets, the law of one price should prevail. In this case, assets of the same risk issued or traded in different markets should command identical expected returns. More precisely, the price of risk as the factor in the asset pricing also must be priced identically across the markets where the asset is traded. As evidence that markets are fully integrated, the empirical study must show that only world risk factors are relevant in explaining the dynamics of expected returns across markets. Harvey (1995) tested an international version of CAPM (ICAPM), and used the MSCI world market index as a proxy of the world market to measure worldwide market systematic risk. The results show a low significance of the global betas for almost all emerging markets.

Other studies on capital market integration can also be found in the following papers amongst abundant literature in this area of study. Buch (2004) did an extensive study of literature in the financial market integration research area, especially for the bond markets in the Euro countries. Adler and Dumas (1983) studied co-variances of asset returns and inflation rates in all countries, 
meanwhile the examination on two-factor models can be traced back to the works of Ferson and Harvey (1994) and Harvey (1995) where an aggregate index of currency returns is introduced to the single-factor ICAPM. The exchange rate factor is, however, found to have marginal explanatory power over the 1976-1992 period in describing the dynamics of emerging market returns.

For investors, the more integrated the markets are, the fewer the benefits of forming an internationally diversified portfolio. This is because when markets are becoming more integrated; asset prices are highly covaried, such that reducing diversifiable risk would be less feasible. In addition, it is not only the asset price or returns that are covaried, but also the volatility. Thus, the costs associated with the higher degree of market integration are at their least in the form of lower opportunity to diversify assets and the higher chances of accepting imported volatility and shocks from the other markets. In previous empirical studies, we can find some supporting evidence of contagion or volatility spill-over. For example, King and Wadhwani (1990) test for an increase in stock market correlations between the United States, the United Kingdom, and Japan and find that cross-market correlations increased significantly after the US market crash in 1987. Lee and Kim (1993) extend this analysis to 12 major markets and find further evidence of contagion: average weekly crossmarket correlations increased from 0.23 before the 1987 US crash to 0.39 afterwards. Calvo and Reinhart (1996) used this approach to test for contagion in stock prices and Brady bonds after the 1994 Mexican peso crisis. They find that cross-market correlations increased for many emerging markets during the crisis. To summarize, each of these tests based on cross-market correlation coefficients reach the same general conclusion: there was a statistically significant increase in crossmarket correlation coefficients during the relevant crisis and, therefore, contagion occurred.

However, in the later period, the comovement in conditional cross-variances was re-examined by Forbes and Rigobon (2002). They found that there was a high level of market co-movement in all the periods of the analyzed sample, not only during the crisis. The result indicates that the degree of integration should be stable and high. In such a situation, the benefit of forming an internationally diversified portfolio would vanish quickly, as a market shock in one country is transmitted instantaneously to the other markets.

In examining the completeness of the integration, the empirical researches above were mainly based on a multi-factor model that comprises several systematic risk factors: the worldwide market risk, the exchange rate risk, the changes in commodity prices, the inflation rate, and the world business cycle. The results from previous studies show that inclusion of the additional factors does not help to improve the model's explanatory power, compared to the single- and two-factor models.

However, as to the critiques of the CAPM itself (see, for example Fama and French, 2004) the above-presented empirical results are unable to offer us a definitive conclusion as to whether the asset-pricing models are misspecified or that the full market integration is not a feasible assumption for the markets. The misspecification of the model is not only because of the inclusion of inappropriate additional risk factors, but also because the proxy of the world market portfolio may not be lying in the efficient fron- 
tier, and/or at a tangent of the capital market line. The author seeks to overcome the latter by constructing a world market portfolio from the composing assets and performing a Merton procedure for deriving the efficient frontier and the capital market line (Setiawan 2012). By doing so, a world portfolio that is mean-variance efficient and at the tangency of the capital market line is assured. The results indicate that markets are completely integrated when we applied the model that assumes completely integrated markets and disregards the hetorscadasticity and interdependence of the markets returns. Since the above constructed world market portfolio is not a common practice in the real world, this paper investigates the use of the
MSCI World Index as a proxy of the world market portfolio, for examining the degree of integration and the law of one price on the world market risk premium.

\section{Data}

Using more recent data, the facts presented by Arouri et al. (2010) are confirmed. From Figure 1, it is apparent that the emerging markets outperformed the developed markets. The correlation of returns between the world index (ACWI) and emerging market index (EM) is 0.956; it is significantly higher than that between the ACWI and the developed market index (EAFE), 0.776. Meanwhile, Table 1 shows that the emerging

\section{Figure 1. MSCI Indexes 1987:1-2012:9}

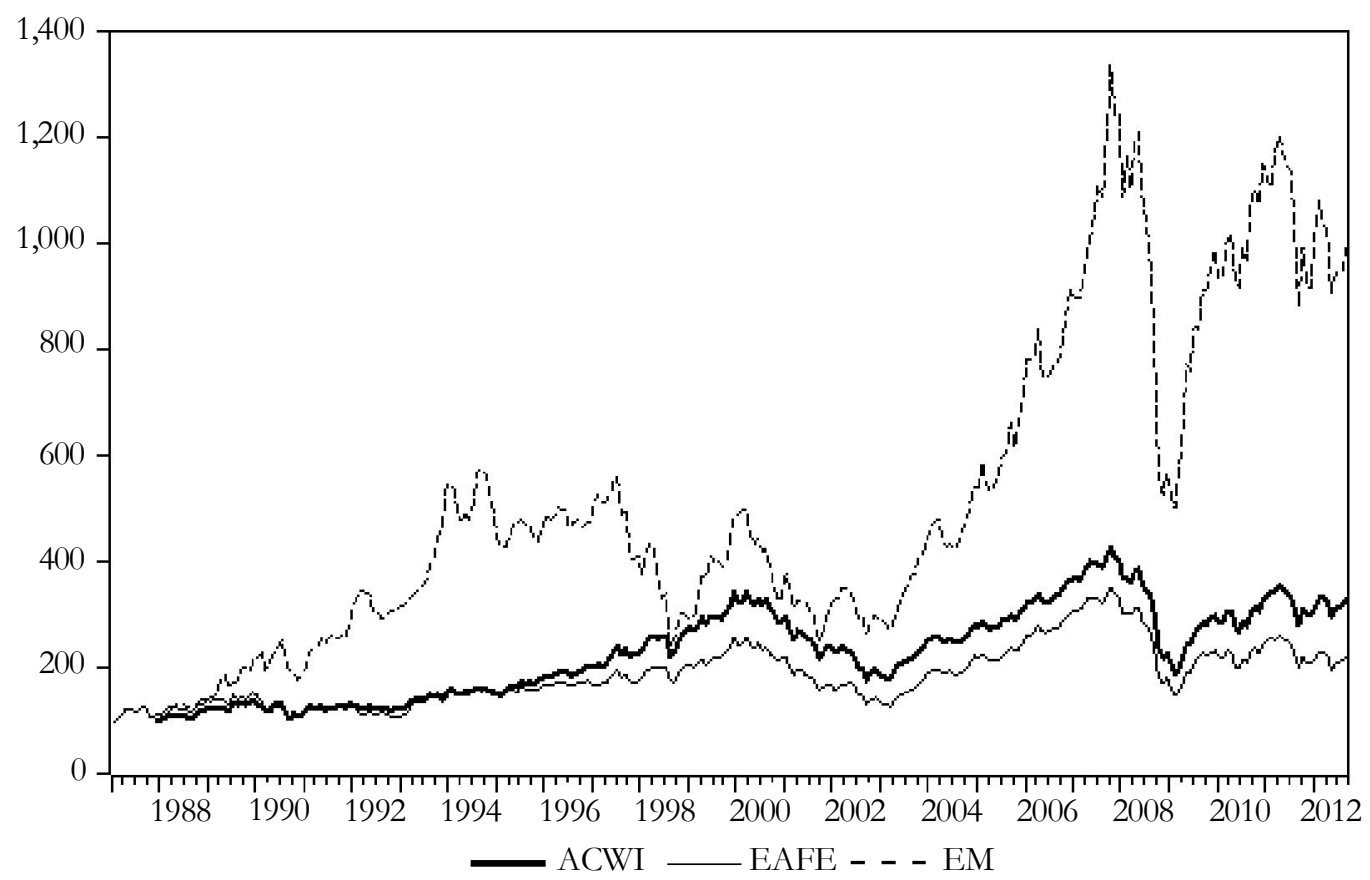

Note: ACWI represents the MSCI world market index that includes both the developed market index (EAFE) and the emerging market index (EM). All indexes are value-weighted indexes. Source: MSCI's website (www.msci.com), plotted by author. 
markets have higher average monthly returns and standard deviations than those of the developed markets.

The international assets in this study consist of 12 stock market indexes from different countries: US-S\&P500 (US), German-DAX (GE), Hong Kong-Hang Seng (HK), Japan-Nikkei225 (JP), SingaporeStrait Times (SI), United Kingdom FTSE100 (UK), Argentina-MERVAL (AR), BrazilBOVESPA (BR), China-SSEC (CH), Indonesia-IHSG (ID), Malaysia-KLSE (MA),

Table 1. Monthly Returns Statistics of MSCI Indexes 1987:1-2012:9

\begin{tabular}{lccc}
\hline & ACWI & EAFE & EM \\
\hline Mean & 0.004 & 0.002 & 0.008 \\
Std. Dev. & 0.046 & 0.052 & 0.071 \\
\hline
\end{tabular}

Source: www.msci.com, computed by author and Mexico-IPC (ME). The market indexes are adjusted to a US dollar value by multiplying them with the local currency per US dollar value exchange rate. The MSCI ACWI index was obtained from MSCI's website (http://www.msci.com), the other market indexes were obtained from Yahoo Finance (http:// finance.yahoo.com), and the exchange rates were obtained from OANDA (http://www.oanda.com).

The test of CAPM for international assets pricing in the US uses monthly observations from $1997 \mathrm{~m} 7$ until $2012 \mathrm{~m} 7$. The riskfree asset is represented by US 3-month Tbills, while the world market portfolio is proxied by the MSCI ACWI index.

A plot of the excess returns of developed markets and emerging markets is shown in Figures 2 and 3, respectively. In both figures, we can observe that the volatility of the excess returns was higher during crises;

Figure 2. Excess Returns of Developed Markets in the U.S. Market

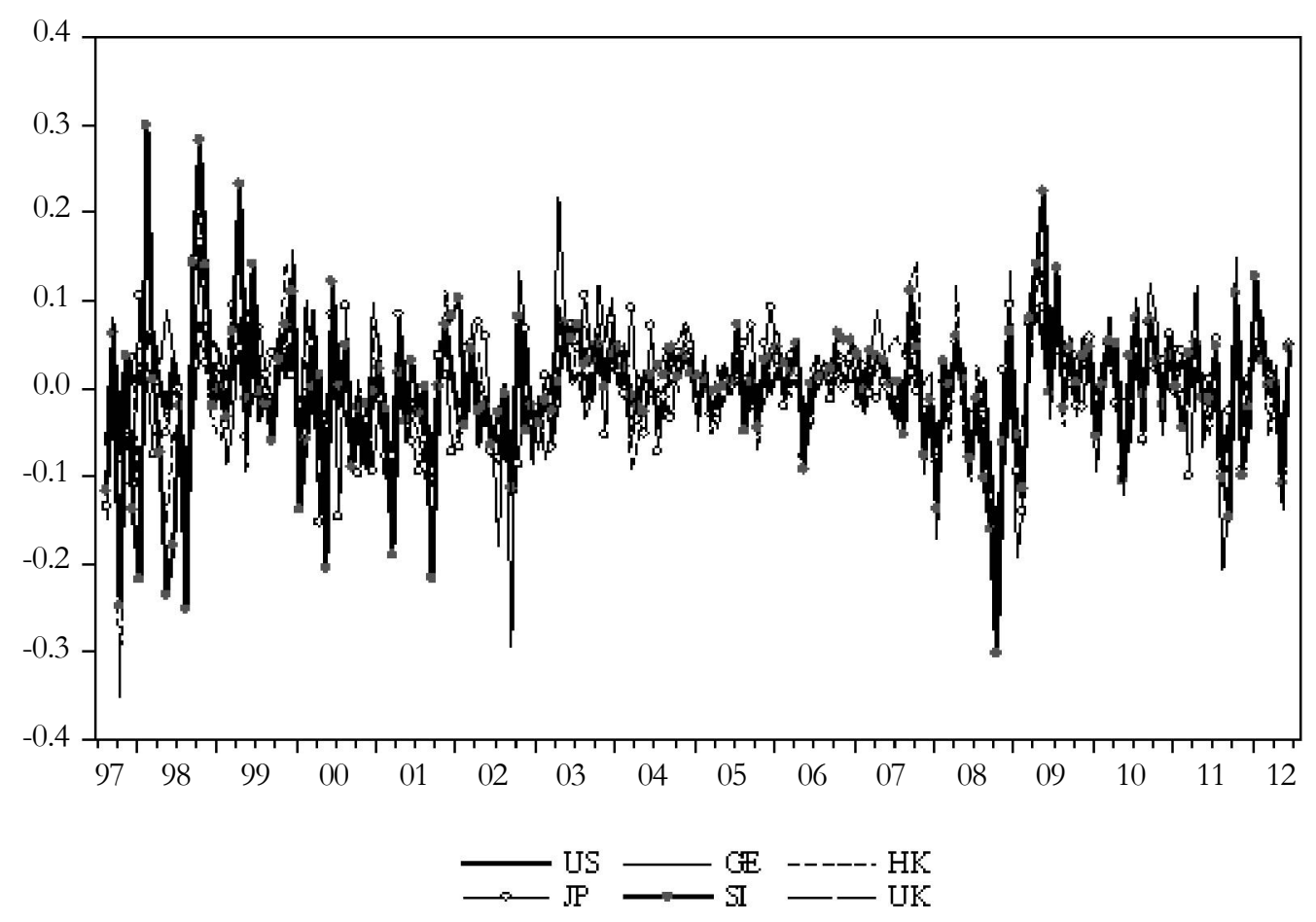




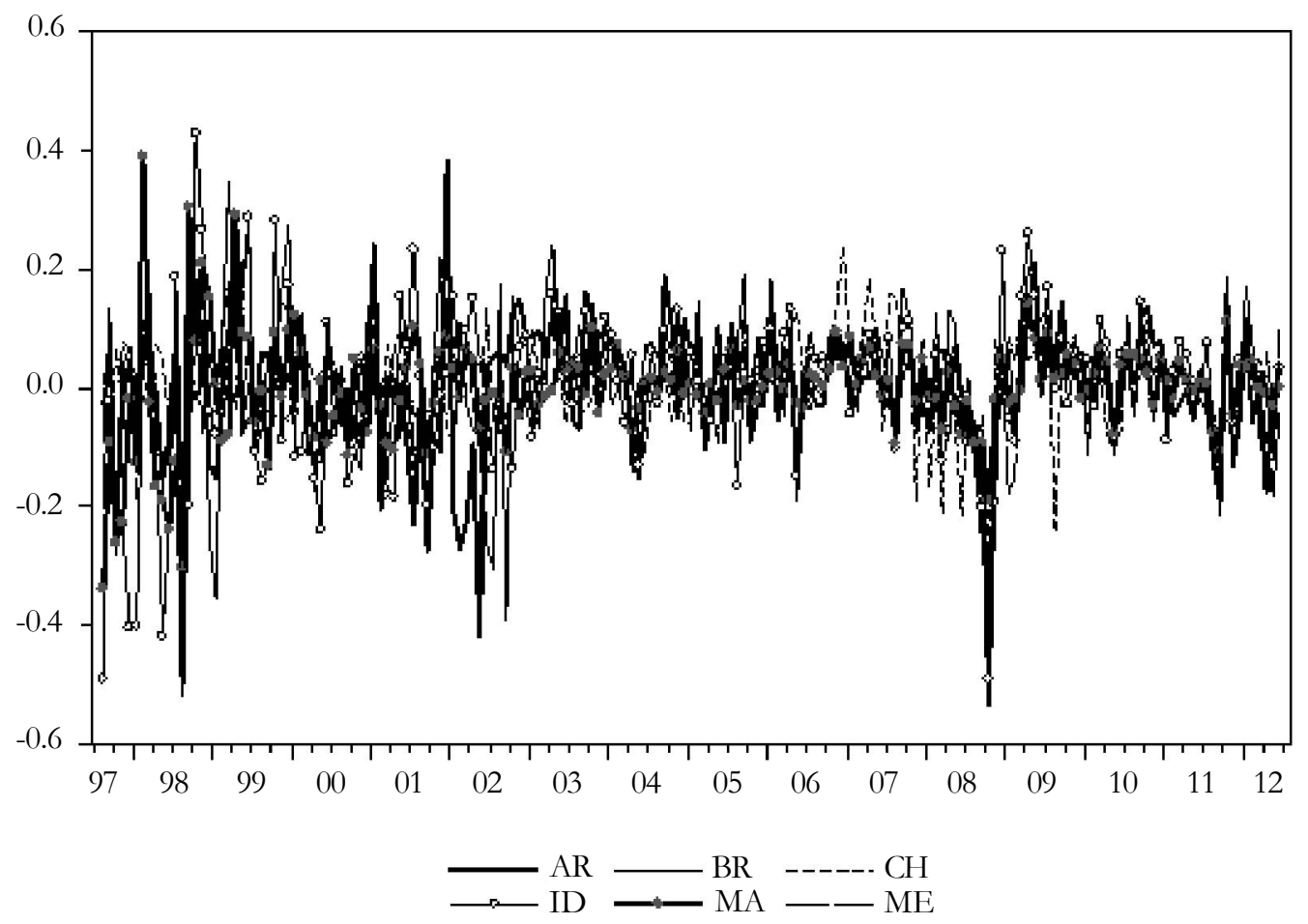

such volatility clustering indicates that a GARCH error structure might exist. The figures also show that the excess returns of the stock markets were co-varied.

\section{Asset Pricing Models}

This paper utilized the capital asset pricing model (CAPM) with time-varying beta. In addition, the homogeneity of the world market risk premium across the markets will be investigated to indicate whether the law of one price in risk pricing holds. The latter also indicates the degree of integration of the stock markets being analyzed.

CAPM is one of the most popular asset pricing methods in use. The model was independently developed by Jack Treynor (1961, 1962), William Sharpe (1964), John Lintner (1965) and Jan Mossin (1966). One important contribution to the easy understanding of CAPM was the work of Robert C. Merton (1972), in his work in providing an analytical solution to the following portfolio choice problem: Given the expected returns and the matrix of co-variances of returns for $n$ individual assets, find the set of portfolio weights that minimizes the variance of the portfolio for each feasible portfolio expected return. The latter is known as a method to obtain the efficient frontier.

\section{Issues in Testing CAPM}

As a theory, CAPM justifies the practice of investing in a broad market portfolio of stocks and bonds. This insight has led to the growth of "indexed" mutual funds and exchange-traded funds (ETFs) that hold market-weighted portfolios of stocks and bonds (Pennacchi 2008: 61). The use of market- 
weighted portfolios of stocks as a proxy of the market portfolio has been extensively found in many previous empirical works that examined CAPM. However, as earlier mentioned in the derivation of CAPM, the market porfolio is not only a mean-variance (risky-only) efficient portfolio, but also a tangency portfolio of the capital market line. The findings in previous empirical works that reject CAPM may be attributed to the use of "false" market portfolios, such as a market capitalization weighted index (i.e. S\&P500 index in the US stock market). Such an index may be a mean-variance efficient portfolio, but we cannot be assured that the index is also the tangency portfolio. The same issue also prevails in applying and testing CAPM for international asset pricing; previous empirical works usually relied on a "world index" such as the MSCI world index as the proxy of the world market portfolio.

The CAPM defined:

$$
\left(\bar{R}-R_{f} e\right)=\frac{\sigma_{M}}{\sigma_{m}^{2}}\left(\bar{R}_{M}-R_{f}\right)=\beta\left(\bar{R}_{M}-R_{f}\right)
$$

where $\bar{R}$ is a vector of national stock markets returns $\left(\widehat{\mathrm{R}}_{\mathrm{i}}\right), R_{f}$ is a scalar of risk free rate in a country where other stock market indexes are traded, $\beta=\frac{\sigma_{M}}{\sigma_{m}^{2}}$ is the $n \times 1$ vector whose $i^{\text {th }}$ element is $\beta_{i}=\frac{\operatorname{Cov}\left(\hat{R}_{m}, \hat{R}_{i}\right)}{\operatorname{Var}\left(\hat{R}_{m}\right)}$. The CAPM in (1) states that there is a linear relationship between excess expected return of an asset $\left(\hat{R}_{i}-R_{f}\right)$ and the market risk $\beta_{i}$.

It requires an estimation of $\beta_{i}$. An unbiased estimate of it can be obtained by running an Ordinary Least Square (OLS) regression of asset $i$ 's excess return on the market portfolio's excess return. The orthogonal, mean-zero residual of the OLS is sometimes referred to as an idiosyncratic, unsystematic, or diversifiable risk. This is the particular asset's risk that is eliminated or diversified away when the asset is held in the market portfolio. Since the individual who invests optimally can eliminate this portion of the asset's risk, there is no "price" or "risk premium" attached to it in the sense that the asset's equilibrium expected return is not altered by it.

When we want to apply CAPM for international asset pricing, the orthogonality of the residuals must hold if the markets where the international assets come from are completely integrated. Assuming that the markets are completely integrated, CAPM can be tested and/or applied in a cross-section regression framework or equation-by-equation OLS in a dynamic time series setting. As the main theme in this paper on dynamic international asset pricing, CAPM with time-varying beta can be tested in the following model:

$$
\left(R_{i, t}-R_{f, t}\right)=\hat{a}_{i}+\hat{b}_{i} \cdot \hat{\widehat{\beta}}_{i, t}+\hat{l}_{i} \cdot \widehat{\widehat{\sigma}}_{i, t}+\hat{\varepsilon}_{i, t}
$$

The model in (2) is a modified version of the cross-section test model for CAPM in which we let the market risk $\left(\hat{\hat{\beta}}_{i, t}\right)$ for each asset vary across time and assets. In addition, a measure of home bias is added by a variable of the conditional standard deviation of the residuals $\left(\widehat{\hat{\sigma}}_{\mathrm{i}, \mathrm{t}}\right)$. In order to obtain $\hat{\hat{\beta}}_{i, t}$, we may apply the diagonal BEKK multivariate GARCH model. In the diagonal BEKK model, the system mean equation consists of returns of both risky asset $i$ and the (world) market return as the dependent variables, and constants as the independent variables. From the Diagonal Model we obtain conditional variance-covariance matrix $\widehat{H}_{t}$ for each time 
$t$ in which the positive definiteness of the matrix is assured. Having the conditional variance/co-variance matrix in hand, we can estimate $\hat{\beta}_{i, t}=\frac{\hat{h}_{t}(i, M)}{\hat{h}_{t}^{2}(M)}$, where $\hat{h}_{t}(i, M)$ and $\hat{h}_{t}^{2}(M)$ are conditional co-variance between the return of asset $i$ and the market return $M$, at time $t$, and conditional market return (M) variance at time $t$ respectively. Model (2) hence could be estimated by equation-byequation GARCH model. One of the univariate GARCH models that may be used for estimating the parameters in (2) is the EGARCH model.

The variance specification for model (2) is assumed to follow EGARCH(1,1) as follows:

$$
\begin{array}{r}
\log \left(\hat{\sigma}_{t}^{2}\right)=\widehat{w}+\hat{\delta} \log \left(\hat{\sigma}_{t-1}^{2}\right)+ \\
\hat{\psi}\left|\frac{\hat{\varepsilon}_{t-1}}{\hat{\sigma}_{t-1}}\right|+\hat{\kappa} \frac{\hat{\varepsilon}_{t-1}}{\hat{\sigma}_{t-1}}
\end{array}
$$

The parameters in (2) and (3) are stored in vector $\theta$ and are estimated by a maximum likelihood estimation (MLE) method. Assuming that errors in (2) are normally distributed, the contribution to the log-likelihood for observation $t$ is:

$$
\begin{aligned}
L(\theta)= & -\left(\frac{T}{2}\right) \log (2 \pi)- \\
& \frac{1}{2}\left[\log \left(\hat{\sigma}_{t}^{2}\right)-\frac{\hat{\varepsilon}_{t}^{2}}{\hat{\sigma}_{t}^{2}}\right]
\end{aligned}
$$

Testing model (2) as an estimation on equation-by-equation univariate $\mathrm{GARCH}$ model implies that $E\left(\varepsilon_{i, t}, \varepsilon_{j, t}\right)=0$ for $i \neq j$. In other words, we are assuming that the idiosyncratic risk, as represented by is uncorrelated with that of the other markets, and if CAPM is true, then we should only be con- cerned with the systematic or market risk represented by the beta.

However, as mentioned earlier in previous sections, many empirical works on testing and measuring the degree of financial market integration often found that financial markets around the world were not completely integrated (partially or mildly integrated). As a consequence, the idiosyncratic risk (in this context, it may also be called the country-specific risk) in each market is often found to be correlated with that of the other markets. Thus, tests of CAPM based on OLS that ignore the co-variance of the residuals may become inefficient in estimating the parameters in the test model. This is what will be addressed in this paper. To overcome the issues, the author also examined the CAPM for international asset pricing using Seemingly Unrelated Regression (SUR) and SUR with GARCH.

\section{Findings}

As pointed out by Chelley-Steely et al. (1998), the markets are said to be integrated if we fail to find a co-integrating equation among the markets (if a co-integrating equation exists, one may do arbitrage by utilizing published information in the past). Table 2 shows Johansen's Co-integration test for pairs of stock markets returns and the world market returns (MSCI ACWI). The Argentine stock market seems to have a long-term relationship with the world stock market; historical prices of the world index might be used for estimating the returns of the Argentinian market. Among the developed stock markets, the Japanese stock market is the market with the lowest degree of integration to the world market, as we can see from the trace statistic and maximum eigenvalue statistic that is just 
Table 2. Cointegration Test between the Domestic Market and World Market

\begin{tabular}{lccccccc}
\hline & $\begin{array}{l}\text { Eigen } \\
\text { value }\end{array}$ & $\begin{array}{c}\text { Trace } \\
\text { Stat. }\end{array}$ & $\begin{array}{c}\mathbf{0 . 0 5} \\
\text { Trace } \\
\text { Crit.val. }\end{array}$ & $\begin{array}{c}\text { Trace } \\
\text { p-Value* }\end{array}$ & $\begin{array}{c}\text { Max-Eigen } \\
\text { Stat. }\end{array}$ & $\begin{array}{c}\mathbf{0 . 0 5} \\
\text { Max.Eig. } \\
\text { Crit.val. }\end{array}$ & $\begin{array}{c}\text { Max.Eig. } \\
\text { p-value* }\end{array}$ \\
\hline US & 0.041 & 9.539 & 20.262 & 0.685 & 7.428 & 15.892 & 0.617 \\
GE & 0.041 & 10.821 & 20.262 & 0.559 & 7.567 & 15.892 & 0.600 \\
HK & 0.043 & 11.016 & 20.262 & 0.541 & 7.790 & 15.892 & 0.573 \\
JP & 0.081 & 19.455 & 20.262 & 0.064 & 15.106 & 15.892 & 0.066 \\
SI & 0.035 & 7.822 & 20.262 & 0.839 & 6.439 & 15.892 & 0.737 \\
UK & 0.030 & 8.293 & 20.262 & 0.800 & 5.537 & 15.892 & 0.838 \\
AR & 0.086 & 21.219 & 20.262 & 0.037 & 16.168 & 15.892 & 0.045 \\
BR & 0.035 & 7.126 & 20.262 & 0.889 & 6.296 & 15.892 & 0.754 \\
CH & 0.043 & 11.374 & 20.262 & 0.506 & 7.897 & 15.892 & 0.560 \\
ID & 0.035 & 7.326 & 20.262 & 0.876 & 6.416 & 15.892 & 0.740 \\
MA & 0.035 & 8.117 & 20.262 & 0.815 & 6.378 & 15.892 & 0.744 \\
ME & 0.037 & 9.601 & 20.262 & 0.679 & 6.696 & 15.892 & 0.706 \\
\hline
\end{tabular}

The series is $\log$ (market index) where the market index is US dollar-adjusted .

Test specification: intercept (no trend) in CE, no intercept in VAR, lag order: 1.

*MacKinnon-Haug-Michelis (1999) p-values, Null Hypothesis: no CE.

the second highest after the Argentinian stock market (one co-integrating equation is found to be below the 7 percent percent significance level). These findings are evidence that the stock markets were not completely integrated, even for the developed stock markets such as the Tokyo Stock Exchange.

Testing CAPM using an equation-byequation estimation of model (2) implies that we ignore two important properties of the data: (i) the existence of GARCH errors structure, and (ii) stock markets were not completely integrated such that the idiosyncratic risk (also known as the diversifiable risk) cannot be completely removed by forming an internationally diversified portfolio. The re- sult of the CAPM test under this setting can be seen in Table 3.

As we can see in Table 3, using the 10 percent significance level, CAPM is rejected for estimating the excess stock market returns of Singapore, Argentina, China, Indonesia, and Malaysia. The premia for market risk (beta) are also different across the assets. It indicates that the market risk is priced differently for assets from foreign markets. Moreover, the idiosyncratic risk seems to be priced in some markets (Argentina and China), while the common world factor (beta) is not priced significantly. From this test, one may conclude that CAPM does not work for pricing the international assets. However, note that we ig- 
Table 3. Conditional Beta CAPM Test for International Assets-EGARCH

\begin{tabular}{lccccccccc}
\hline & $\hat{a}$ & S.E. $(\hat{a})$ & p-val. $(\hat{a})$ & $\hat{b}$ & S.E. $(\hat{b})$ & p-val. $(\hat{b})$ & $\hat{l}$ & \multicolumn{2}{c}{ S.E. $(\hat{\imath})$ p-val $(\hat{l})$} \\
\hline US & -0.006 & 0.012 & 0.600 & 0.001 & 0.005 & 0.741 & 0.116 & 0.293 & 0.693 \\
GE & -0.006 & 0.027 & 0.827 & 0.004 & 0.003 & 0.137 & 0.023 & 0.370 & 0.951 \\
HK & 0.026 & 0.016 & 0.107 & -0.005 & 0.004 & 0.211 & -0.228 & 0.239 & 0.339 \\
JP & 0.015 & 0.025 & 0.556 & 0.015 & 0.005 & 0.001 & -0.533 & 0.454 & 0.240 \\
SI & 0.025 & 0.013 & 0.057 & -0.004 & 0.003 & 0.180 & -0.224 & 0.216 & 0.299 \\
UK & 0.001 & 0.015 & 0.954 & 0.007 & 0.005 & 0.120 & -0.158 & 0.343 & 0.644 \\
AR & 0.066 & 0.034 & 0.051 & 0.001 & 0.004 & 0.840 & -0.662 & 0.319 & 0.038 \\
BR & 0.041 & 0.030 & 0.169 & -0.004 & 0.001 & 0.006 & -0.233 & 0.281 & 0.407 \\
CH & -0.169 & 0.095 & 0.075 & -0.003 & 0.002 & 0.223 & 2.290 & 1.252 & 0.067 \\
ID & 0.051 & 0.030 & 0.089 & -0.001 & 0.002 & 0.582 & -0.441 & 0.280 & 0.115 \\
MA & 0.022 & 0.013 & 0.081 & -0.002 & 0.002 & 0.418 & -0.268 & 0.217 & 0.217 \\
ME & 0.869 & 2.367 & 0.713 & -0.001 & 0.002 & 0.512 & -9.974 & 27.236 & 0.714 \\
\hline
\end{tabular}

The results are based on the equation-by-equation EGARCH model, where the mean equation is specified by $\left(R_{i, t}-R_{f, t}\right)=\hat{a}+\hat{b} \cdot \hat{\hat{\beta}}_{i, t}+\hat{l} . \hat{\sigma}_{i, t}+\hat{\varepsilon}_{i, t} \hat{\varepsilon}_{i, t} \sim E G A R C H$, by assuming that $E\left(\varepsilon_{i, t} \varepsilon_{j, t}\right)=0$ for $i \neq j$.

Table 4. Cross-Correlation of CAPM Residuals

\begin{tabular}{|c|c|c|c|c|c|c|c|c|c|c|c|c|}
\hline & US & GE & HK & $\mathbf{J P}$ & SI & UK & $\mathrm{AR}$ & $\mathrm{BR}$ & $\mathrm{OH}$ & ID & MA & $\mathrm{ME}$ \\
\hline \multirow[t]{2}{*}{ US } & 1 & & & & & & & & & & & \\
\hline & - & & & & & & & & & & & \\
\hline \multirow[t]{2}{*}{ GE } & 0.823 & 1 & & & & & & & & & & \\
\hline & 0.000 & - & & & & & & & & & & \\
\hline \multirow[t]{2}{*}{$\mathrm{HK}$} & 0.662 & 0.627 & 1 & & & & & & & & & \\
\hline & 0.000 & 0.000 & - & & & & & & & & & \\
\hline \multirow[t]{2}{*}{$\mathbb{P}$} & 0.626 & 0.545 & 0.529 & 1 & & & & & & & & \\
\hline & 0.000 & 0.000 & 0.000 & - & & & & & & & & \\
\hline \multirow[t]{2}{*}{ SI } & 0.672 & 0.586 & 0.815 & 0.525 & 1 & & & & & & & \\
\hline & 0.000 & 0.000 & 0.000 & 0.000 & - & & & & & & & \\
\hline \multirow[t]{2}{*}{ UK } & 0.834 & 0.825 & 0.693 & 0.600 & 0.649 & 1 & & & & & & \\
\hline & 0.000 & 0.000 & 0.000 & 0.000 & 0.000 & - & & & & & & \\
\hline
\end{tabular}


Table 4 (Continued)

\begin{tabular}{|c|c|c|c|c|c|c|c|c|c|c|c|c|}
\hline & US & GE & HK & JP & SI & UK & $\mathrm{AR}$ & $\mathrm{BR}$ & $\mathrm{CH}$ & ID & MA & $\mathbf{M E}$ \\
\hline \multirow[t]{2}{*}{$\mathrm{AR}$} & 0.446 & 0.456 & 0.515 & 0.340 & 0.555 & 0.473 & 1 & & & & & \\
\hline & 0.000 & 0.000 & 0.000 & 0.000 & 0.000 & 0.000 & - & & & & & \\
\hline \multirow[t]{2}{*}{$\mathrm{BR}$} & 0.670 & 0.645 & 0.673 & 0.465 & 0.612 & 0.664 & 0.583 & 1 & & & & \\
\hline & 0.000 & 0.000 & 0.000 & 0.000 & 0.000 & 0.000 & 0.000 & - & & & & \\
\hline \multirow[t]{2}{*}{$\mathrm{CH}$} & 0.283 & 0.288 & 0.289 & 0.173 & 0.215 & 0.264 & 0.255 & 0.288 & 1 & & & \\
\hline & 0.000 & 0.000 & 0.000 & 0.020 & 0.004 & 0.000 & 0.001 & 0.000 & - & & & \\
\hline \multirow[t]{2}{*}{$\mathbb{D}$} & 0.471 & 0.439 & 0.541 & 0.431 & 0.709 & 0.462 & 0.380 & 0.448 & 0.179 & 1 & & \\
\hline & 0.000 & 0.000 & 0.000 & 0.000 & 0.000 & 0.000 & 0.000 & 0.000 & 0.017 & - & & \\
\hline \multirow[t]{2}{*}{ MA } & 0.471 & 0.410 & 0.593 & 0.277 & 0.691 & 0.399 & 0.420 & 0.414 & 0.233 & 0.556 & 1 & \\
\hline & 0.000 & 0.000 & 0.000 & 0.000 & 0.000 & 0.000 & 0.000 & 0.000 & 0.002 & 0.000 & - & \\
\hline \multirow[t]{2}{*}{$\mathrm{ME}$} & 0.685 & 0.587 & 0.614 & 0.477 & 0.657 & 0.618 & 0.612 & 0.660 & 0.231 & 0.416 & 0.369 & 1 \\
\hline & 0.000 & 0.000 & 0.000 & 0.000 & 0.000 & 0.000 & 0.000 & 0.000 & 0.002 & 0.000 & 0.000 & 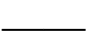 \\
\hline
\end{tabular}

The numbers in italic are $\mathrm{p}$-values

nore two important properties in our data that were previously mentioned. Thus, the rejection of CAPM in this test may be caused by the specification error in estimating the model.

Testing CAPM using equation-by-equation estimation for each asset ignores the fact that the idiosyncratic risks that represent the market-specific characteristics are still correlated with those of the other market. The risk is not completely removed by the diversification. Table 4 shows that cross-correlation of CAPM residuals is found in almost all markets. Knowing this property, tests of CAPM under seemingly unrelated regression (SUR) should be more appropriate to tackle the issue. Table 5 shows the results under the SUR framework [the idiosyncratic risk was excluded from model (2)].

Under the SUR framework, CAPM fits well for international asset pricing. Although we found that CAPM seems unfit to be applied to Japanese assets, the joint hypothesis that $\hat{a}_{i}=0, \forall i$ cannot be rejected. The result indicates that beta risk is the only factor that matters in estimating the excess returns. Moreover, the estimated market risk premium (in absolute value) is also found to be identical across the assets. It may indicate that the market risk is priced equally, regardless of where the assets come from. An asset that has a negative market risk premium indicates that the asset mostly has a negative correlation with the market portfolio during the period of analysis, such that it is most likely that this asset is frequently being sold short.

Now CAPM is shown favourably under the latter test. However, there is one remaining problem that has not been addressed by SUR: the multivariate GARCH errors structure in the model. Model (2) can be estimated as a system equation of SUR, as was done 
Table 5. Conditional Beta CAPM Test for International Assets-SUR

\begin{tabular}{ccccccc}
\hline & $\hat{a}$ & S.E. $(\hat{a})$ & p-val. $(\hat{a})$ & $\hat{b}$ & S.E. $(\hat{b})$ & p-val. $(\hat{b})$ \\
\hline US & 0.000 & 0.004 & 0.906 & -0.001 & 0.003 & 0.746 \\
GE & 0.003 & 0.007 & 0.663 & -0.002 & 0.003 & 0.590 \\
HK & -0.004 & 0.007 & 0.524 & 0.002 & 0.002 & 0.374 \\
JP & -0.013 & 0.005 & 0.016 & 0.010 & 0.003 & 0.002 \\
SI & 0.002 & 0.007 & 0.820 & 0.000 & 0.002 & 0.773 \\
UK & -0.005 & 0.004 & 0.245 & 0.005 & 0.003 & 0.141 \\
AR & -0.004 & 0.010 & 0.717 & -0.001 & 0.004 & 0.799 \\
BR & 0.003 & 0.010 & 0.737 & 0.000 & 0.001 & 0.753 \\
CH & 0.007 & 0.006 & 0.291 & -0.004 & 0.002 & 0.079 \\
ID & 0.001 & 0.010 & 0.949 & 0.000 & 0.002 & 0.871 \\
MA & -0.002 & 0.007 & 0.755 & 0.001 & 0.002 & 0.603 \\
ME & 0.005 & 0.007 & 0.433 & 0.000 & 0.001 & 0.641 \\
\hline Wald Coefficients Test: & $\chi^{2}$ Stat. & p-val $\left(H_{0}^{1}\right)$ & & $\chi^{2}$ Stat. & p-val $\left(H_{0}^{2}\right)$ & \\
\hline$H_{0}^{1}: \hat{a}_{i}=0, \forall i$ & 18.049 & 0.114 & & & & \\
$H_{0}^{2}:\left|\hat{b}_{1}\right|=\left|\hat{b}_{2}\right|=\cdots=\left|\hat{b}_{12}\right|$ & & & & 13.049 & 0.290 & \\
\hline
\end{tabular}

earlier. However, in SUR estimation, the errors are assumed to correlate in cross section, but are homoscedastic or have a constant variance/co-variance matrix. As we can see in Figure 2 and Figure 3, volatility clustering in the excess returns is very likely to be present. Applying a diagonal BEKK for testing the CAPM (model (2) specifies the mean equation of each asset in the SUR system equation), we may tackle the presence of the errors structure.

Table 6 shows the CAPM test results under the SUR-GARCH model. The estimated parameters were obtained from the diagonal BEKK model estimated by maximum likelihood estimation (MLE). A test of the joint hypothesis that all intercepts are 0 cannot be rejected. However, the significance level for rejecting the homogeneity of market risk premia is increasing. Under the 10 percent significance level, we reject that the market risk premia are identical across the assets. The latter indicates that the market risk is priced differently for assets from different markets.

The test under the SUR-GARCH framework warns us that ignoring the cross-correlation of error terms in the CAPM test model and the multivariate GARCH errors structure may significantly change the verdict of the applicability of CAPM in pricing the international assets. 
Table 6. Conditional Beta CAPM Test for International Assets By SUR-GARCH (MLE)

\begin{tabular}{ccccccc}
\hline & $\hat{a}$ & S.E.( $(\hat{a})$ & p-val.( $(\hat{a})$ & $\hat{b}$ & S.E. $(\hat{b})$ & p-val. $(\hat{b})$ \\
\hline US & -0.002 & 0.004 & 0.691 & -0.001 & 0.004 & 0.787 \\
GE & -0.003 & 0.007 & 0.638 & 0.000 & 0.004 & 0.947 \\
HK & -0.001 & 0.006 & 0.830 & 0.001 & 0.003 & 0.751 \\
JP & -0.017 & 0.006 & 0.002 & 0.013 & 0.003 & 0.000 \\
SI & 0.001 & 0.004 & 0.750 & 0.000 & 0.002 & 0.875 \\
UK & -0.006 & 0.004 & 0.180 & 0.000 & 0.004 & 0.934 \\
AR & -0.002 & 0.009 & 0.849 & -0.003 & 0.004 & 0.346 \\
BR & 0.006 & 0.011 & 0.545 & -0.001 & 0.002 & 0.446 \\
CH & 0.001 & 0.007 & 0.886 & -0.002 & 0.003 & 0.430 \\
ID & 0.011 & 0.008 & 0.167 & -0.002 & 0.002 & 0.331 \\
MA & 0.002 & 0.005 & 0.636 & 0.000 & 0.002 & 0.792 \\
ME & 0.003 & 0.007 & 0.699 & 0.000 & 0.001 & 0.853 \\
\hline
\end{tabular}

Applying SUR-GARCH enables us to test dynamic beta CAPM under both completely integrated (the idiosyncratic risk is uncorrelated with that of other markets) or partially integrated markets (the idiosyncratic risk may be correlated with that of other markets). This is the advantage of using the SUR-GARCH framework in testing CAPM. However, as the number of assets we want to analyze is increasing, the number of parameters to be estimated is exploding, such that the MLE is becoming unfeasible.

In the empirical example of the test above, we used the monthly data from 15year observations (180 observations). In that situation the MLE is still feasible and we can see the results as shown in Table 6. When high frequency (i.e., weekly or daily) data are used in the analysis, the MLE fails to estimate the parameters. This is the disadvantage of using the MLE.

\section{Summary and Conclusions}

We found that CAPM is fully applicable and the risk premiums for the assets are equal when an OLS estimation was carried out. However, when heteroscedasticity and incompleteness of the market integration were considered, CAPM could not be justified as a good model for pricing the international assets. Given the results above, there is some 
inconsistency with regard to drawing conclusions about the applicability of CAPM in international assets pricing. This inconsistency may be due to the estimation method being used for the test, as described earlier. The other possible reason is because of the world market portfolio. The MSCI ACWI index is a value-weighted index, meaning that the proportion of assets from different markets in the index is always non-negative. The index is traded as an ETF in some markets around the world, including in the US. Note that the MSCI ACWI index or its derivative index (ETF) directly tracks the price of the composing assets in the other markets, regardless of the dynamics of the demand of the index, let us say, in the US. Thus, the weights of the assets in that portfolio (index) were not obtained from an optimization problem as assumed by CAPM. Although the composing assets in that index may include all possible representative assets from almost all stock markets around the world, we cannot be assured that such an index is not only meanvariance efficient, but also the tangency portfolio of the capital market line. With regard to this issue, the rejection of CAPM in a test using such an index as a proxy of the world market portfolio may also be due to the inappropriate world market proxy.

\section{References}

Adler, M., and B. Dumas. 1983. International portfolio choice and corporation finance: A synthesis. Journal of Finance 38 (3): 925-984.

Arouri, M. E. H, F. Jawadi, and D. K. Nguyen. 2010. The Dynamics of Emerging Stock Markets, Empirical Assessments and Implications. Berlin Heidelberg: Physica-Verlag (Springer).

Calvo, S., and C. M. Reinhart. 1996. Capital flows to Latin America: Is there evidence of contagion effects? In Guillermo A. C., M. Goldstein, and E. Hochreiter (Ed.), Private Capital Flows to Emerging Markets After the Mexican Crisis. Washington, DC: Institute for International Economics.

Buch, C. M. 2004. Globalization of Financial Markets, Causes of Incomplete Integration and Consequences for Economic Policy. Germany: Springer.

Chelley-Steely, P. L., J. M. Steeley, and E. J. Pentecost. 1998. Exchange controls and European stock market integration. Applied Economics 30 (2): 263-267.

Fama, E. F., and K. R. French. 2004. The capital asset pricing model: Theory and evidence. Journal of Economic Perspectives 18: 25-46.

Ferson, W. E., and C. R. Harvey. 1994. Sources of risk and expected returns in global equity markets. Journal of Banking and Finance 18 (4): 775-803.

Forbes, K. J., and R. Rigobon. 2002. No contagion, only interdependence: Measuring stock market comovements. Journal of Finance 57 (5): 2223-2261.

Harvey, C. R. 1995. Predictable risk and returns in emerging markets. Review of Financial Studies 8 (3): 773816.

King, M. A., and S. Wadhwani. 1990. Transmission of volatility between stock markets. Review of Financial Studies 3: 5-33.

Lee, S. B., and K. J. Kim. 1993. Does the October 1987 crash strengthen the comovements among national stock markets? Review of Financial Economics 3: 89-102. 
Lintner, J. 1965. The valuation of risk assets and the selection of risky investments in stock portfolios and capital budgets. Review of Economics and Statistics 47 (1): 13-37.

Merton, R. C. 1972. An analytical derivation of the efficient portfolio frontier. Journal of Financial and Quantitative Analysis 7: 1851-1872.

Mossin, J. 1966. Equilibrium in a capital asset market. Econometrica 34 (4): 768-783.

Mundell, R. A. 1963. Capital mobility and stabilization policy under fixed and flexible exchange rates. The Canadian Journal of Economics and Political Science/ Revue canadienne d'Economique et de Science politique 29 (4): 475-485.

Park, Y. C., and C. Wyplosz. 2010. Monetary and Financial Integration in East Asia: The Relevance of European Experience. USA: Oxford University Press.

Pennacchi, G. 2008. Theory of Asset Pricing. Boston, US: Pearson Education Inc.

Sharpe, W. F. 1964. Capital asset prices: A theory of market equilibrium under conditions of risk. Journal of Finance 19 (3): 425-442.

Setiawan, K. 2012. Reexamination of Dynamic Beta International CAPM: A SUR with GARCH approach. Review of Economic and Business Studies 10 (5-2).

Treynor, J. L. 1961. Market value, time, and risk. Unpublished Manuscript.

Treynor, J. L. 1962. Toward a theory of market value of risky assets. Unpublished Manuscript (A final version was published in 1999 in Robert A. Korajczyk (Ed.), Asset Pricing and Portfolio Performance: Models, Strategy and Performance Metrics (pp. 15-22). London: Risk Books. 
